
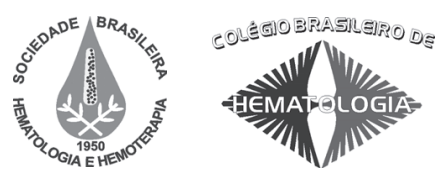

Carta ao Editor / Letter to Editor

\section{Bacteremia possibly caused by Curtobacterium spp found in a blood culture from a central venous line of a pediatric leukemia patient who underwent bone marrow transplantation}

\section{Bacteremia possivelmente causada por Curtobacterium spp encontrado na cultura do sangue de um cateter venoso num paciente pediátrico submetido a transplante de medula óssea}

\author{
Cristina Viana-Niero ${ }^{l}$ \\ Guilherme F. Perini ${ }^{2}$ \\ Carolina Kassab \\ Marinês D. V. Martino ${ }^{l}$ \\ Jacyr Pasternak ${ }^{1}$
}

${ }^{l}$ Physician - Clinical microbiologist, Clinical Laboratory, Albert Einstein Hospital

${ }^{2}$ Physician - Fellow in Hematology, Albert Einstein Hospital

${ }^{3}$ Physician - Resident in Hematology, Albert Einstein Hospital

\section{To Editor}

Sepsis caused by coryneform bacteria is probably underdiagnosed: diphtheroids are usually considered contaminants when obtained in blood cultures. ${ }^{1}$ Identification of those bacteria is complex with phenotyping and commercial identification systems not being useful. Funke et al. ${ }^{1}$ first described the isolation of Curtobacterium spp from human clinical specimens in 2005.

Curtobacteria are known plant pathogens that grow better at $30^{\circ} \mathrm{C}$, and not the normal temperature of $35^{\circ} \mathrm{C}$ that is used for growing blood culture isolates. Phenotyping is complex and based on cellular fatty acid profiles, a tool that is not commonly available in clinical laboratories. ${ }^{2}$ rRNA sequencing is a new tool for the identification of isolates that are not usually identified in commercially available systems. ${ }^{3}$

\section{Case Report}

We recently consulted a 2 -year-old child who had undergone an unsuccessful cord blood transplantation, and who was then submitted to successful haploidentical bone marrow transplantation for juvenile chronic myelomonocytic leukemia on April 19 2008. He developed grade II skin graft versus host disease and had a Hickman central venous catheter implanted.

At 40 days post transplantation he developed fever, pulmonary infiltrates, had a low-grade cytomegalovirus viremia ( 1 positive cell/300,000 granulocytes) and was readmitted in the hospital. Blood cultures were obtained through the Hickman catheter and he was empirically treated with gancyclovir (IV, $5 \mathrm{mg} / \mathrm{kg}$, twice daily), ceftriaxone (IV, $100 \mathrm{mg} / \mathrm{kg} /$ day), prednisone (VO, $2 \mathrm{mg} / \mathrm{kg} /$ day) and klaritromycin (IV, $7.5 / \mathrm{kg}$ twice daily). His pulmonary infiltrates worsened over three days, with tachypnea but no frank respiratory distress; he was comfortable on ambient air. Ceftriaxone and klaritromycin were then discontinued and cefepime (IV, $50 \mathrm{mg} / \mathrm{kg}$ twice daily) added to his regimen. The catheter exit site was clean, with no local evidence of infection. The child improved, pulmonary infiltrates regressed and the catheter was not changed. No further febrile episodes occurred and the child was discharged without further medical problems 12 days after re-admission. He remains on ampicillin due to our protocol of prophylaxis for pneumococcal infection, and remains well.

In the blood culture obtained from the Hickman catheter, a gram-positive, delicate rod, with yellow colonies, which proved to be oxidase-positive, grew in one aerobic flask with agar. The coryneform organism was identified by $16 \mathrm{~S}$ sequencing using the MicroSequens 500 16S rRNA gene analysis kit (Applied Biosystem, Foster City, USA). Consensus sequence was identified by similarity with the Kit Microseq database and confirmed in the Genebank database using the "Blast" (Basic Local Alignment Search Tool) and deposited under \# FJ429845. This sequence is $99.8 \%$ similar to the Curtobacterium spp sequence of the Microseq database and $99 \%$ similar to Curtobacterium spp sequences from the GeneBank, access \# AM41064, AY 88361, AY 688360 and AY 688359.

\section{Discussion}

We did not prove that pneumonia in this case was caused by a Curtobacterium spp or that the febrile episode was a catheter-related bacteremia. Diphtheroid bacteria are usually considered contaminants in blood cultures, but infection is also possible in severely immunosuppressed patients. As Funke et al. ${ }^{1}$ discuss in their paper, as soon as a genus is described in the clinical microbiological literature, other clinical microbiologists will find it: sometimes as a clear cause of infection, sometimes as a possible cause, as in this case.

\section{Resumo}

Microbiologistas clínicos devem estar atentos à possibilidade de bacteremia relacionada com cateter causada por infecção difteróide, como possivelmente foi o caso neste relato, no qual um 
menino de dois anos, portador de um cateter venoso central para tratamento de leucemia, apresentou pneumonia. A cultura do sangue obtido no cateter revelou Curtobacterium spp. Rev. Bras. Hematol. Hemoter. 2009;31(3):205-206.

Palavras-chave: Sepse; infecções bacterianas Gram-positivas, imunossupressão.

\section{Referências Bibliográficas}

1. Funke G, Aravena-Roman M, Frodl R. First description of Cutrobacterium spp. isolated from human clinical specimens. J Clin Microbiol. 2005;43:1032-6.

2. Funke G, Lucchini GM, Pfyffer GE, Marchiani M, von Graevenitz A. Characteristics of CDC group 1 and goup 1-like coryneform bacteria isolated from clinical specimens. J Clin Microbiol. 1993; 31:2907-12.

3. Fontana C, Favaro M, Pelliccioni M, Pistoia ES, Favalli C. Use of the MicroSeq 500 16S rRNA gene-based sequencing for identification of bacterial isolates that commercial automated systems failed to identify correctly. J Clin Microbiol. 2005; 43:615-9.

Avaliação: Editor e dois revisores externos

Conflito de interesse: não declarado

Recebido: 26/02/2009

Aceito: $12 / 03 / 2009$

Hospital Israelita Albert Einstein

Correspondência: Jacyr Pasternak

Centro de Pesquisa Clínica, Instituto Israelita de Ensino e Pesquisa Albert Einstein

Av. Albert Einstein, 627/701, Piso Chinuch

05651-901 - São Paulo-SP - Brazil

E-mails:jpaster@einstein.br

hamer@einstein.br 